\title{
Konaklama işletmelerine yönelik iş ilanlarının içerik analizi yöntemi ile incelenmesi: Kariyer.net örneği*
}

\section{Analysis of job advertisements for accommodation businesses by content analysis method: Kariyer.net example}

Gönderim Tarihi / Received: 18.11.2021

Bilge VÍLLi**1

Kabul Tarihi / Accepted: 26.12.2021

Esat SAÇES ${ }^{2}$

doi https://doi.org/10.31795/baunsobed.1025490

ÖZ: Bu çalışmanın amacı, kariyer.net isimli internet sitesinde iş ilanı veren konaklama işletmelerinin iş ilanlarını inceleyerek ilanların amaca uygunluğunu araştırmaktır. Bu amaca ulaşmak için nitel araştırma yöntemlerinden biri olan içerik analizi kullanılmıştır. Kariyer.net sitesinde yer alan 218 adet iş ilanı altı kategoride incelenmiştir. Bu kategoriler; ilanda işletme ile ilgili detaylı bilginin bulunurluğu, genel nitelikler ve iş tanımının ayrı ayrı belirtilip belirtilmediği, adaya sağlanacak sosyal imkanlar/yan haklar bilgisi, ilanda görsel bulunup bulunması (logo, fotoğraf, video vb.), ilanda iş tanımının bulunup bulunmadığı bilgisi ve ilandaki bilgi miktarıdır (kelime sayısı). Araştırmadan elde edilen sonuçlara göre; oda kahvaltı hizmeti veren 5 yıldızlı oteller diğer yıldız sayılı otellere göre iş ilanlarında daha fazla kelime kullanmaktadır. Oda fiyatı 1501-2000 TL arasında olan otellerin diğer fiyatlara sahip otellere göre iş ilanlarında daha fazla "iş tanımı" bilgisine, kelime sayısına ve görsel kullanımına yer verdiği görülmektedir. Adaylara sağlanacak sosyal imkanlar/yan haklar bilgisi sadece 5 yıldızlı otellerde yer almaktadır. Ayrıca Trivago puanı yüksek olan otellerin iş ilanında daha fazla kelime kullandıkları tespit edilmiştir.

Anahtar Kelimeler: İş ilanları, Konaklama işletmeleri, İçerik analizi, Kariyer.net

ABSTRACT: The aim of this study is to examine the job postings of the accommodation businesses that post job advertisements on the website named kariyer.net and to investigate the suitability of the advertisements for the purpose. Content analysis, one of the qualitative research methods, was used to achieve this aim. 218 job postings on Kariyer.net were analyzed in six categories. These categories are; Availability of detailed information about the business in the advertisement, whether the general qualifications and job description are specified separately, information on the social benefits / fringe benefits to be provided to the candidate, whether there is an image (logo, photo, video, etc.), whether there is a job description in the advertisement, and information in the advertisement is the amount (word count). According to the results obtained from the research; 5-star hotels providing bed and breakfast service use more words in their job postings compared to other star-numbered hotels. It is seen that the hotels with room rates between 1501 and 2000 TL include more "job description" information, the number of words and the use of images in their job advertisements compared to hotels with other prices. Information on social benefits/benefits to be provided to candidates is only available in 5-star hotels. In addition, it has been determined that hotels with a high Trivago score use more words in their job advertisements.

Keywords: Job postings, Hospitality enterprises, Content analysis, Kariyer.net

\footnotetext{
${ }^{*}$ Bu çalışma 21. Ulusal Turizm Kongresinde bildiri olarak sunulmuştur.

** Sorumlu Yazar / Corresponding Author

1 Öğr. Gör. Dr., Balıkesir Üniversitesi/Sındırgı MYO/Yönetim ve Organizasyon Bölümü/İşletme Yönetimi Programı, bilgevilli@balikesir.edu.tr, (1) https://orcid.org/0000-0002-1175-2043

${ }^{2}$ Öğr. Gör. Dr., Balıkesir Üniversitesi/Sındırgı MYO/Otel, Lokanta ve İkram Hizmetleri Bölümü/Turizm ve Otel İşletmeciliği Porgram1, esackes@balikesir.edu.tr, (1) https://orcid.org/0000-0001-6592-4077
} 


\section{EXTENDED ABSTRACT}

\section{Literature review}

The most important resource for achieving organizational goals in tourism and hospitality enterprises is the workforce. However, the turnover rate is high due to the tourism industry's long working hours, limited social opportunities, low wages and seasonal work (Wasmuth \& Davis, 1983: Cho et al., 2006). High employee turnover causes many problems in labor-intensive accommodation enterprises. Because the labor costs in accommodation enterprises are high and difficult to control. The cost of labor in accommodation establishments constitutes $35-40 \%$ of the total costs (Yenipınar, 2005; 89-90). According to Hogan (1992), the direct and indirect total cost of an intermediate employee to leave the business varies between $\$ 1,400$ and $\$ 4,000$, while this figure varies between $\$ 17,000$ and $\$ 20,000$ for a general manager. Although these calculations are not considered to be very reliable, it is a fact accepted by everyone that the cost of employee turnover is high enough to affect the profitability of the accommodation enterprises (Stalcup \& Pearson, 2001). A successful HRM implementation will help hospitality businesses to cope with high labor turnover, absenteeism, job dissatisfaction and turnover (Hoque, 2013). Another reason for the high turnover rate in the hospitality industry is the wrong recruitment policies of the accommodation companies. Failure to attract appropriate job applications to the business is an important problem.

\section{Methodology}

Content analysis, one of the qualitative research methods, was used to determine the quality criteria. 218 job postings on kariyer.net were examined in six categories. These categories are; the presence of detailed information about the business in the advertisement, whether the general characteristics and job description are specified separately, the social facility/benefit rights to be provided to the candidate, whether there is a job in the advertisement (logo, photo, video, etc.) and the number of words in the job advertisement. During the analysis period, the repetitive and similar concepts in job postings were brought together and the data were tabulated using the opinions of both experts (tourism and marketing academics).

\section{Findings and discussion}

When we look at the general tables created from the data obtained as a result of the content analysis, it is seen that only 5 -star hotels use 201 or more words in their job advertisements in terms of the number of words used in the advertisements according to the number of stars. The rate of those who use 201 or more words is $24 \%$. In general, $42 \%$ of the hotels used between 51 and 100 words in their job postings. According to these results, it can be said that human resources processes and human resources management activities are more advanced in five-star accommodation establishments.

Due to the complex nature of the service provided by accommodation establishments, all departments work at the same time. For this reason, accommodation businesses need personnel with different expertise. When the distribution of the examined job postings according to the positions is examined, it is seen that the staff is mostly needed in the front office, kitchen and service units. Erdem \& Gezen (2014) reached similar results in their study. Erdem \& Gezen (2014) concluded that in the job advertisements they examined, front office, food-beverage and housekeeping staff were needed the most. Because these units are the units that need the most employees in accommodation establishments. These units are also among the basic parts of accommodation establishments; it is one of the departments that bring direct income to these businesses (especially the front office and food and beverage) (Batman, 1999: 117-118). While examining the advertisements, they were divided into departments according to the application positions and evaluated with criteria. The striking finding at this stage is that hotels seeking staff for bar, kitchen and service use more than 201 words in their job postings compared to hotels seeking housekeeping and front office staff.

When viewed as an incoming; 5-star hotels that provide bed and breakfast service give more importance to job postings. As room prices increase, hotels make more effort to select personnel that will offer high value to their customers and are more careful in their job postings. It can also be said that hotels with high Trivago scores give more weight to job postings to find qualified personnel. 


\section{Results and recommendations}

172 out of 218 job advertisements reviewed were provided by 5 star hotels. 5 -star hotels use more "word count" (amount of information) and "visual" (logo, photo, video, etc.) in job postings compared to other star-rated businesses. It can be said that especially 5 star hotels that provide bed and breakfast use more words and images in their job advertisements. According to these results, it can be said that the human resources processes and human resources management activities of 5-star hotels have improved and also the indicators of being an employer brand exist at a basic level. One of the important criteria in job postings is "job description" information. The existence of a job definition is crucial to reaching the right candidates with the qualifications required by the job. Thanks to the job description, the candidate gets information about where he / she will work, where he / she will be located, the responsibilities and limits he / she will have. It also saves HR specialists and managers from wasting time. Therefore, businesses should include job descriptions in job postings. According to the research results, $44 \%$ of 218 job postings have job descriptions. It is seen that most of the advertisements examined in this study do not include the information on social opportunities / benefits provided to the person. This information is only available in a small part of 5 star hotels. In his study, Blackman (2006) concluded that one of the most important factors affecting people in job postings is "information about social opportunities and career opportunities". It can be said that accommodation companies must include this information in their job postings in order to attract qualified personnel to the facility and to create a large candidate pool. 


\section{Giriş}

İnternet kavramının ortaya çıkışı ve yaygın olarak kullanılması ile birlikte iş arama şekilleri tamamen değişmiştir. İnternet iş arayan kişiler ile eleman arayan işletmelerin kolayca bir araya gelmesine olanak sağlamıştır. $\mathrm{Bu}$ sayede günümüzde iş arayan kişilerin iş başvurusunda bulunabilmek için geleneksel yöntemleri (gazete ilanları veya doğrudan işletmeye bireysel olarak yapılan iş başvuruları gibi) kullanmasına gerek kalmamıştır. İnternet iş arayan kişilere istedikleri nitelikte iş bulma ve kariyer geliştirme olanağı sağlarken, işletmelere de daha çok nitelikli elemana ulaşma ve internet sitelerinde bulunan özgeçmiş formlarının potansiyel adaylar tarafından doldurulması ile çok geniş ve değerli bir veri tabanı oluşturma imkânı sağlamaktadır. Ayrıca internet, sadece ülke içerisinde yaşayan işgücü potansiyelinin ülkelerarası ve kıtalararası transferinin de gerçekleşmesine olanak sağlamaktadır.

İş ilanları ve işe alım süreçleri ile ilgili uluslararası literatür incelendiğinde bu konu ile ilgili yapılan birçok çalışmanın olduğu görülmektedir (Fisher vd., 1979; Belt ve Paolillo, 1982; Rynes ve Miller (1983); Kaplan vd., 1991; Gatewood vd., 1993; Goltz ve Gianantonio 1995; Turban ve Greening, 1996; Yüce ve Highhouse, 1998; Fernandes ve Rosen, 2000; Reeve ve Schultz, 2004; Roberson vd., 2005; Feldman vd., 2006; Blackman, 2006; Lee vd. 2013). Bu konu ile ilgili Türkiye'deki literatür incelendiğinde ise birkaç çalışma ile sınırlı olduğundan (Baş, vd., 2011; Acarlar ve Bilgiç, 2013; Erdem ve Gezen, 2014; Alnıç̧1k, 2016; Ertaş, 2018; Oğuzbalaban, 2019) dolayı araştırmadan elde edilen bulguların ilgili alana katkı sağlayacağı düşünülmektedir. Bu çalışma ile kariyer.net sitesinde konaklama işletmeleri tarafından verilen iş ilanları incelenerek; işletmelerin iş ilanlarının amaca uygunluğunun belirli kriterlere göre araştırılması amaçlanmaktadır. Çalışmanın benzer çalışmalardan ayrıldığı en önemli husus, çalışmanın yapıldığı dönemdeki dünya çapında gerçekleşen pandemi koşullarının etkisi içinde verilen iş ilanlarının araştırılmasıdır. Ayrıca çalışmanın uygulamacılara etkili iş ilanları hazırlama konusunda yararlı ipuçları sunması da bu çalışmayı yapılan diğer çalışmalardan farklılaştırmaktadır.

\section{Literatür taraması}

İnsan Kaynakları Yönetimi (IKKY) kavramı, işgücünü etkili ve verimli bir şekilde yönetmek için ideolojik bir çerçeve olarak 1970'lerin sonunda Avrupa ve Avustralya'da akademik bir teori, bir uygulama alanı ve yönetsel bir meslek olarak ortaya çıkmıştır (Beardwell ve Claydon, 2007). Genel olarak insan kaynakları yönetimi, örgütlerde çalışan kişilerin istihdamı, gelişimi ve refahına yönelik olan stratejik, bütünleşik ve tutarlı bir yaklaşım olarak ifade edilebilir. İKY "örgütsel misyonu, hedefleri ve stratejileri desteklemek amaciyla yetenekli ve enerjik işgücünü çekme, geliştirme ve sürdürme süreci” olarak tanımlanmıştır (Schermerhorn, 2001:240). Boxall ve Purcell (2003:1) insan kaynakları yönetimini "firmadaki istihdam ilişkilerinin yönetimi ile ilgili tüm faaliyetler" olarak tanımlamışlardır.

İşletmeyi temsil eden personelin çoğu pek çok hizmet süreci aşamasında müşterilerin hizmet kalitesi ve değer yaratma algılamalarını önemli bir şekilde etkiler. Bundan dolayı personelin pek çoğu pazarlama faaliyeti ile yakından ilişkili faaliyetler yaparlar (Koç, 2016). Koç’un (2003) çalışmasında hizmet personeli önemli bir pazarlama iletişimi unsuru olarak ortaya çıkmıştır. Hizmet işletmelerinde insan kaynakları yönetimi fonksiyonu imalat sanayi işletmelerindekinden daha önemlidir. Koç (2003) tarafından seyahat acenteleri ile ilgili yapılan çalışmada müşterilerin hizmeti değerlendirmelerinde seyahat acentesi personelinin tutumlarının, davranışlarının ve iletişimlerinin önemli ölçüde etkili olduğunu ortaya koymuştur. Etkileşim yoğunluğu ve çeşitlilik arttıkça hizmet sunan personelin daha iyi seçilmesi ve eğitilmesi gereği ortaya çıkacaktır. Audretsch ve Thurik $(2000,2001)$ işletmeleri nitelikli işgücü sıkıntısıyla birlikte daha yüksek eğitimli çalışanlara duyulan ihtiyacın çifte zorluğu ile karşı karşıya kaldıklarından, yeni "bilgiye dayalı" ekonomide etkili İKY uygulamalarının giderek daha önemli hale geldiğini savunmaktadır.

İKY ile ilgili literatür incelendiğinde, işletmelerin uyguladıkları başarılı IKKY stratejileri açık bir şekilde verimliliğin ve işletme performansının artmasına katkı sağlamaktadır (Chen vd., 2003; Huselid, 1995; Heffernan ve Flood, 2000; Cho, 2005; Wood vd., 2006). Huselid (1995) çalışmasında İK uygulamalarının örgütsel performans üzerinde etkili olduğu sonucuna ulaşmıştır. İK uygulamaları ve karlılık ilişkisi ile ilgili çalışmalar incelendiğinde söz konusu uygulamaların karlılık üzerinde etkili olduğu sonucu ortaya çıkmaktadır (Roberts, 1995; Huselid, 1995; Wright ve Boswell, 2002). 


\section{Turizm ve konaklama işletmelerinde insan kaynakları yönetiminin önemi}

Turizm sektörü dünya gayri safi milli hasılasının \%9,5'ini oluşturan büyük bir ekonomik alan olmakla beraber dünyadaki her 11 istihdamdan 1'ine sahip olan önemli bir sektördür (Şit, 2016). Birleşmiş Milletler Dünya Turizm Örgütü'ne (UNTWO) (2019) göre Dünya çapındaki uluslararası turist hareketleri (gecelik ziyaretçiler) 2019 yılında \%4 büyüyerek 1,5 milyar seviyesine ulaşmıştır. Turizm ve konaklama işletmelerinde örgütsel amaçlara ulaşmada en önemli kaynak işgücüdür. Ancak turizm endüstrisinin kısıtlı sosyal olanaklar, uzun mesai saatleri, sezonluk çalışma ve düşük ücretler gibi özellikler taşımasından dolayı işgören devir hızı yüksektir (Wasmuth ve Davis, 1983: Cho vd., 2006). Yapılan birçok araştırma otelcilik sektöründe işgören devir hızının yüksek olduğunu ortaya koymaktadır. Örneğin Amerika'da yapılan bir araştırmaya göre, Amerika'da bulunan otellerde çalışan devir hızı $\% 92$ oranındadır. Türkiye' de yapılan bir araştırmada ise, Marmaris'teki otellerde çalışan devir hızı oranı \%59, İstanbul ve Ankara' daki otellerde ise \%30 olarak bulunmuştur. Bu oran yeni aç1lan (1 2 yıl) otellerde \%100-200 arasındadır (Birdir, 2000:142). Çalışan devrinin yüksek olması emek yoğun olan konaklama işletmelerinde birçok soruna yol açmaktadır. Çünkü konaklama işletmelerinde iş̧̧ilik maliyetleri yüksek ve denetlemesi zordur. Konaklama işletmelerinde işçilik maliyeti toplam maliyetlerin ortalama \%35-40'nı oluşturur (Yenipınar, 2005:89-90). Hogan'a (1992) göre konaklama işletmelerinde bir ara elemanın işten ayrılmasının işletmeye doğrudan ve dolaylı toplam maliyeti 1.400 \$ ile $4.000 \$$ arasında değişirken, bu rakam bir genel müdür için 17.000 \$ ile 20.000 \$ arasında değişmektedir. Her ne kadar bu hesaplamalar çok güvenilir olarak kabul görmese de, çalışan devir hızının yüksek olmasının maliyetinin konaklama işletmelerinin karlılığını etkileyecek derecede yüksek olduğu herkes tarafından kabul edilen bir olgudur (Stalcup ve Pearson, 2001).

Etkili insan kaynakları yönetimi, bir konaklama işletmesi için rekabet avantajı yaratmada ve sürdürmede en önemli hususlardan biridir. Konaklama işletmelerinin emek yoğun yapısı ve kaliteli hizmetin sunulması için çalışanların yaratacağı katma değer, IKY uygulamalarının konaklama işletmeleri için ne kadar önemli olduğu gerçeğini ortaya çıkarmaktadır. Başarılı bir İKY uygulaması konaklama işletmelerinin yüksek işgücü devir hızı, işe devamsızlık, iş memnuniyetsizliği ve işten ayrılma gibi olumsuzluklarla baş etmesinde yardımcı olacaktır (Hoque, 2013). Otelcilik sektöründe işgören devir hızının yüksek olmasının sebeplerinden bir diğeri de konaklama işletmelerinin yanlış işe alım politikaları uygulamalarıdır. Uygun nitelikteki iş başvurularını işletmeye çekememek önemli bir sorundur.

Konaklama işletmelerinin amaçladıkları başarıya ulaşmaları, yeterli sayıda ve nitelikte istihdam edilen insan kaynağına bağlıdır. İnsan unsurunun bilgisi, becerisi ve bunları kullanma yeteneği sayesinde maddi kaynakların etkin kullanımı gerçekleşmektedir. İnsan kaynakları departmanının en önemli işlevlerinden birisi işe alım sürecidir. Bu süreçte iki hususa çok dikkat edilmelidir. Bunlardan ilki iş analizinin doğru bir şekilde yapılmasıdır. İş analizi yapılırken işin gereklerinin neler olduğu, işletmenin işgörenden neler beklediği eksiksiz ve açik bir şekilde belirlenmelidir. İkincisi ise bu işi yapacak olan işgörenin sahip olması gereken nitelik ve özelliklerin neler olduğunun belirlenmesidir. İse alım süreci boş olan pozisyonlara işgören bulmak değil, doğru işe doğru iş görenleri bulmaktır. Yani işin gerektirdiği nitelikteki ve sayıdaki çalışanları kendilerine çekmektir. Bu sürecin iyi yönetilmemesi hem örgütsel hem de bireysel açıdan önemli sorunların ortaya çıkmasına neden olabilir. Örgütsel açıdan bakıldığında; hizmet içi eğitim giderlerinin artmasına, etkinlik ve verimliliğin düşmesine, işletmedeki diğer çalışanların motivasyonunun düşmesine, iş kazalarının yaşanmasına, çalışan devir hızının artmasına ve bunun sonucu işlerin aksamasına neden olur. $\mathrm{Bu}$ süreç işgören açısından değerlendirildiğinde ise işgörenin yeteneklerine uygun olmayan bir işte çalıştırılmasından dolayı bunalıma girmesi veya iş doyumsuzluğu yaşaması durumu ortaya çıkabilir. Konaklama işletmeleri iş ilanları için sıklıkla gazete ve özellikle internet sitelerini kullanmaktadır. Gazetelere ilan verilirken dikkat gösterilmesi gereken en önemli nokta, iş ilanının hedef kitle için en uygun zaman ve yerde verilmesi, ilanın içeriğinin işe başvurma konusunda potansiyel adayları teşvik etmesi, iş ilanına uygun olmayan adayların ise başvuru yapmasını engelleyecek şekilde hazırlanmış olmasıdır (Erdem ve Gezen, 2014). Ancak son yıllarda işletmeler personel bulmak için gazete ilanları yerine daha çok internet sitelerini tercih etmektedir. Hem kurumsal internet sayfaları hem de iş ilanlarının bulunduğu internet siteleri işletmeler tarafından yoğun olarak kullanılmaktadır. Bu internet sitelerinden en çok kullanılanlardan birisi kariyer.net' tir. 1999 yılından itibaren iş arama ve işe alım süreçlerinde, iş 
arayanlarla işverenleri internet ortamında bir araya getirmektedir. Kariyer.net'in veri tabanında 25 milyonu aşkın özgeçmiş yer almaktadır. Kariyer.net üyesi işletme sayısı ise 94 binin üzerindedir. İstanbul Ümraniye ve Yeşilköy ofislerinin yanı sıra Adana, Ankara, Antalya, Bursa, Denizli, Elazığ, Eskişehir, Gaziantep, İzmir, Kayseri, Kocaeli, Konya, Mersin, Sakarya ve Samsun'da bulunan ofisleriyle müşteri ve adaylarına hizmet vermektedir (Kariyer.net, 2020). İşletmeler, iş ilanları için internet sitelerini kullanarak aynı anda birçok kişiye ulaşabilmektedir. İş arayan adaylar da farklı şehirlerde farklı ilanları değerlendirebilme firsatına sahip olabilmektedir. Ancak burada dikkat edilmesi gereken bir husus vardır. İnsan kaynakları birimlerinin nitelikli adayları işletmelerine çekebilmeleri için internet sitelerine verecekleri iş ilanlarını titizlikle hazırlamaları gerekmektedir. Özellikle son yıllarda Türkiye'deki turizm yöneticilerinin nitelikli eleman bulma konusunda sıkıntı yaşadıklarına yönelik haberler dikkat çekmektedir (Turizm Günlüğü, 2018-2019; Milliyet, 2018; İşte Çanakkale, 2019).

Yapılan birçok çalışmaya göre iş ilanlarında genel ve yüzeysel bilgiler sunmak yerine daha ayrıntılı bilgiler sunmak adayların başvuru niyetleri üzerinde daha olumlu etkiler yaratmaktadır (Mason ve Belt, 1986; Breaugh ve Billings, 1988; Yüce ve Highhouse, 1998; Barber ve Roehling, 1993; Allen vd., 2004; Roberson, Collins ve Oreg, 2005).

Barber ve Roehling (1993) tarafından yapılan çalışmada bir iş ilanındaki bilgi miktarı ile adayların iş başvurusu yapma kararı arasında pozitif ilişki olduğu ortaya koyulmuştur. İş ilanlarında gerek işin içeriği ile ilgili gerekse çalışanlara sunulan olanaklarla ilgili verilen bilgi miktarı; adayların ilanı veren işletmenin itibarı ile ilgili algılamalarını olumlu yönde etkileyebileceği gibi, işe alma sürecinin olumlu şekilde sonuçlanması olasılığını da artırmaktadır (Feldman vd., 2006). İş ilanında verilen bilginin miktarı kadar işin içeriği de oldukça önemlidir. Eğer iş ilanında verilen bilgi işin kendisi veya ilanı veren işletmeyle alakalı ise, ilan daha olumlu değerlendirilmektedir (Yüce ve Highhouse 1998). Alnıaçık’a göre (2016) ise iş ilanında yer alan bilginin kalitesi ilanı veren işletmenin çekiciliğini ve adayların bu işletmeye iş başvurusu yapma niyetini etkilemektedir.

İş arayan adaylar bu süreçte kendi ilgi alanlarına, bilgi, deneyim ve beceri seviyelerine uygun pozisyonları araştırırlar. Bir pozisyonun kendileri için uygun olup olmadığını değerlendirmek için de ayrıntılı bilgiye ihtiyaç duyarlar. Adaylar, iş arama sürecinde ilan edilen pozisyonlar için iş tanımı, eğitim ve yükselme olanakları, maaş ve yapılacak diğer ödemeler, sosyal imkanlar/yan haklar ve iş çevresi gibi bilgileri değerlendirirler (Cable vd. 2000). Bu bilgileri içermeyen nitelikteki ilanlarda yer alan pozisyonların kendileri için uygun olmadığı sonucuna varabilirler. Diğer taraftan, iş ilanında detaylı bilgilere yer verilmesi halinde ise bazı adaylar istenen özelliklere sahip olmadıklarını düşünebilir, bazıları da ilanda belirtilen işin kendilerine uygun olmadığı düşüncesiyle başvuru yapmaktan vazgeçebilir. Bu durum aynı zamanda aday havuzunda başvurunun azalmasına da neden olabilmektedir (Premack ve Wanous 1986; Schneider vd., 2000).

\section{Yöntem}

Bu çalışmada turizm sektöründe faaliyet gösteren konaklama işletmelerince verilen iş ilanlarının içerik analizi yöntemi ile incelenmesi amaçlanmaktadır. İçerik analizi, önceden belirlenmiş kategorilere göre içeriğin sistematik olarak incelenmesini sağlayan bir tekniktir (Elo ve Kyngas, 2008:108). Analiz süresi boyunca iş ilanlarındaki tekrar eden ve birbirine benzeyen kavramlar bir araya getirilerek, iki uzmanın da görüşlerinden (turizm ve pazarlama akademisyenleri) yararlanılarak veriler tablo haline getirilmiştir. Çalışma sürecinde iş birliği amacıyla veriler ve analizler turizm ve pazarlama alanında çalışan uzmanlarla paylaşılmıştır. Yukarıda bahsedilen analiz sürecinin Brantlinger vd. (2005: 201) tarafından nitel araştırmada geçerlilik ve güvenirliği sağlamada kullanılabilir olduğu belirtilmiştir.

Araştırmanın verilerini "kariyer.net" internet sitesinde, 06.05.2020 tarihinde yayında olan 218 ilan oluşturmaktadır. "Kariyer.net" sitesinin seçilmesinin nedeni ilgili tarihte en çok güncel ilanın bu sitede yer almasıdır. Söz konusu iş ilanlarında yer alan bilgiler on iki kategori halinde incelenmiştir. $\mathrm{Bu}$ kategoriler; ilanda işletme ile ilgili detaylı bilginin bulunurluğu, genel nitelikler ve iş tanımının ayrı ayrı belirtilip belirtilmediği, adaya sağlanacak sosyal imkanlar/yan haklar bilgisi, adayın gece çalışmasına veya vardiyalı çalışmaya uygun olup olmadığı bilgisi, adayın konaklamasının karşılanıp karşılanmayacağı bilgisi, adayın sahip olması gereken kurumsal eğitimler/sertifikalar/belgelerin varlığ 
bilgisi, ilanda görsel bulunup bulunması (logo, fotoğraf, video vb.), iş ilanında adayı özendirici cümlenin bulunup bulunmadığı bilgisi, iş ilanının dili, adayın kullanmayı bildiği bilgisayar yazılımları ve programları, ilanda iş tanımının bulunup bulunmadığı bilgisi ve ilandaki bilgi miktarı (kelime sayısı) olarak on iki kategori olarak belirlenmiştir. Bu kategoriler tek tek incelenmiş ve anlamlı veriler gösterdiği düşünülen altı tanesi seçilmiştir. Bu kategoriler; ilanda işletme ile ilgili detaylı bilginin bulunurluğu, genel nitelikler ve iş tanımının ayrı ayrı belirtilip belirtilmediği, adaya sağlanacak sosyal imkanlar/yan haklar bilgisi, ilanda görsel bulunup bulunmaması (logo, fotoğraf, video vb.), ilanda iş tanımının bulunup bulunmadığı bilgisi ve ilandaki bilgi miktarından (kelime sayısı) oluşmaktadır.

\section{Bulgular ve tartışma}

Konaklama işletmelerinin özelliklerine göre iş ilanlarındaki kriterlerin dağılımı Tablo 1'de yer almaktadır. 
Tablo 1: Konaklama işletmelerinin özelliklerine göre iş ilanlarındaki kriterlerin dağılımı

\begin{tabular}{|c|c|c|c|c|c|c|c|c|c|c|c|c|c|c|c|c|}
\hline \multirow[b]{2}{*}{ Otel Yıldız Sayısı } & \multirow[b]{2}{*}{$\mathrm{n}$} & \multicolumn{2}{|c|}{$\begin{array}{l}\text { İssletme ile } \\
\text { İlgili Detaylı } \\
\text { Bilginin } \\
\text { Bulunurluğu }\end{array}$} & \multicolumn{2}{|c|}{$\begin{array}{c}\text { "Genel } \\
\text { Nitelikler" ve } \\
\text { "İs Tanımı" nın } \\
\text { Ayrı Ayrı } \\
\text { Belirtilip } \\
\text { Belirtilmediği }\end{array}$} & \multicolumn{2}{|c|}{$\begin{array}{c}\text { Adaya } \\
\text { Sağlanacak } \\
\text { Sosyal } \\
\text { İmkanlar/Yan } \\
\text { Haklar Bilgisi }\end{array}$} & \multicolumn{2}{|c|}{$\begin{array}{c}\text { İlanda Görsel } \\
\text { Bulunması } \\
\text { (Logo, Fotoğraf, } \\
\text { Video vb.) }\end{array}$} & \multicolumn{2}{|c|}{$\begin{array}{c}\text { İlanda İş } \\
\text { Tanımı } \\
\text { Varlığı }\end{array}$} & \multicolumn{5}{|c|}{ İlandaki Bilgi Miktarı (Kelime Sayısı) } \\
\hline & & Var & Yok & Var & Yok & Var & Yok & Var & Yok & Var & Yok & $\begin{array}{l}10- \\
50 \\
\end{array}$ & $\begin{array}{l}51- \\
100 \\
\end{array}$ & $\begin{array}{l}101- \\
150 \\
\end{array}$ & $\begin{array}{l}151- \\
200\end{array}$ & $\begin{array}{l}201 \text { ve } \\
\text { üzeri }\end{array}$ \\
\hline 1 yildız & 1 & $0 \%$ & $100 \%$ & $100 \%$ & $0 \%$ & $0 \%$ & $100 \%$ & $0 \%$ & $100 \%$ & $100 \%$ & $0 \%$ & $0 \%$ & $0 \%$ & $100 \%$ & $0 \%$ & $0 \%$ \\
\hline 2 yildız & 2 & $50 \%$ & $50 \%$ & $50 \%$ & $50 \%$ & $0 \%$ & $100 \%$ & $50 \%$ & $50 \%$ & $50 \%$ & $50 \%$ & $0 \%$ & $50 \%$ & $0 \%$ & $50 \%$ & $0 \%$ \\
\hline 3 yıldız & 6 & $17 \%$ & $83 \%$ & $33 \%$ & $67 \%$ & $0 \%$ & $100 \%$ & $50 \%$ & $50 \%$ & $33 \%$ & $67 \%$ & $0 \%$ & $33 \%$ & $67 \%$ & $0 \%$ & $0 \%$ \\
\hline 4 yıldız & 35 & $11 \%$ & $89 \%$ & $26 \%$ & $74 \%$ & $0 \%$ & $100 \%$ & $54 \%$ & $46 \%$ & $34 \%$ & $66 \%$ & $9 \%$ & $60 \%$ & $14 \%$ & $9 \%$ & $9 \%$ \\
\hline 5 yıldız & 172 & $48 \%$ & $52 \%$ & $44 \%$ & $56 \%$ & $7 \%$ & $93 \%$ & $73 \%$ & $27 \%$ & $45 \%$ & $55 \%$ & $2 \%$ & $38 \%$ & $28 \%$ & $8 \%$ & $24 \%$ \\
\hline Butik & 2 & $0 \%$ & $100 \%$ & $100 \%$ & $0 \%$ & $0 \%$ & $100 \%$ & $100 \%$ & $0 \%$ & $100 \%$ & $0 \%$ & $0 \%$ & $100 \%$ & $0 \%$ & $0 \%$ & $0 \%$ \\
\hline Toplam & 218 & $40 \%$ & $60 \%$ & $41 \%$ & $59 \%$ & $6 \%$ & $94 \%$ & $69 \%$ & $31 \%$ & $44 \%$ & $56 \%$ & $3 \%$ & $42 \%$ & $27 \%$ & $8 \%$ & $20 \%$ \\
\hline \multicolumn{17}{|l|}{ Otel Sahipliği } \\
\hline Yabanc1 & 32 & $47 \%$ & $53 \%$ & $56 \%$ & $44 \%$ & $0 \%$ & $100 \%$ & $72 \%$ & $28 \%$ & $56 \%$ & $44 \%$ & $3 \%$ & $34 \%$ & $9 \%$ & $3 \%$ & $50 \%$ \\
\hline Yerli & 163 & $43 \%$ & $57 \%$ & $35 \%$ & $65 \%$ & $7 \%$ & $93 \%$ & $69 \%$ & $31 \%$ & $38 \%$ & $62 \%$ & $2 \%$ & $43 \%$ & $32 \%$ & $9 \%$ & $13 \%$ \\
\hline Ortaklık & 23 & $13 \%$ & $87 \%$ & $65 \%$ & $35 \%$ & $0 \%$ & $100 \%$ & $70 \%$ & $30 \%$ & $65 \%$ & $35 \%$ & $9 \%$ & $48 \%$ & $13 \%$ & $4 \%$ & $26 \%$ \\
\hline Toplam & 218 & $40 \%$ & $60 \%$ & $41 \%$ & $59 \%$ & $6 \%$ & $94 \%$ & $69 \%$ & $31 \%$ & $44 \%$ & $56 \%$ & $3 \%$ & $42 \%$ & $27 \%$ & $8 \%$ & $20 \%$ \\
\hline \multicolumn{17}{|l|}{ Pansiyon Tipi } \\
\hline Herșey Dahil & 68 & $41 \%$ & $59 \%$ & $24 \%$ & $76 \%$ & $18 \%$ & $82 \%$ & $74 \%$ & $26 \%$ & $26 \%$ & $74 \%$ & $0 \%$ & $49 \%$ & $29 \%$ & $12 \%$ & $10 \%$ \\
\hline Oda kahvaltı & 80 & $59 \%$ & $41 \%$ & $65 \%$ & $35 \%$ & $0 \%$ & $100 \%$ & $80 \%$ & $20 \%$ & $65 \%$ & $35 \%$ & $3 \%$ & $26 \%$ & $31 \%$ & $6 \%$ & $34 \%$ \\
\hline Tam pansiyon & 9 & $0 \%$ & $100 \%$ & $11 \%$ & $89 \%$ & $0 \%$ & $100 \%$ & $67 \%$ & $33 \%$ & $33 \%$ & $67 \%$ & $22 \%$ & $44 \%$ & $22 \%$ & $0 \%$ & $11 \%$ \\
\hline Yarım Pansiyon & 4 & $0 \%$ & $100 \%$ & $0 \%$ & $100 \%$ & $0 \%$ & $100 \%$ & $0 \%$ & $100 \%$ & $0 \%$ & $\begin{array}{r}100 \\
\%\end{array}$ & $0 \%$ & $50 \%$ & $50 \%$ & $0 \%$ & $0 \%$ \\
\hline Sadece oda & 57 & $23 \%$ & $77 \%$ & $37 \%$ & $63 \%$ & $0 \%$ & $100 \%$ & $54 \%$ & $46 \%$ & $39 \%$ & $61 \%$ & $5 \%$ & $56 \%$ & $16 \%$ & $7 \%$ & $16 \%$ \\
\hline Toplam & 218 & $40 \%$ & $60 \%$ & $41 \%$ & $59 \%$ & $6 \%$ & $94 \%$ & $69 \%$ & $31 \%$ & $44 \%$ & $56 \%$ & $3 \%$ & $42 \%$ & $27 \%$ & $8 \%$ & $20 \%$ \\
\hline \multicolumn{17}{|l|}{ Trivago Puanı } \\
\hline $7,5 \mathrm{ve}$ alt 1 & 9 & $0 \%$ & $100 \%$ & $44 \%$ & $56 \%$ & $0 \%$ & $100 \%$ & $0 \%$ & $100 \%$ & $44 \%$ & $56 \%$ & $11 \%$ & $67 \%$ & $11 \%$ & $11 \%$ & $0 \%$ \\
\hline $7,6-8,0$ & 17 & $18 \%$ & $82 \%$ & $24 \%$ & $76 \%$ & $0 \%$ & $100 \%$ & $71 \%$ & $29 \%$ & $24 \%$ & $76 \%$ & $0 \%$ & $76 \%$ & $18 \%$ & $6 \%$ & $0 \%$ \\
\hline $8,1-8,5$ & 45 & $51 \%$ & $49 \%$ & $40 \%$ & $60 \%$ & $0 \%$ & $100 \%$ & $67 \%$ & $33 \%$ & $44 \%$ & $56 \%$ & $9 \%$ & $20 \%$ & $44 \%$ & $11 \%$ & $16 \%$ \\
\hline $8,6-9,0$ & 83 & $42 \%$ & $58 \%$ & $37 \%$ & $63 \%$ & $4 \%$ & $96 \%$ & $73 \%$ & $27 \%$ & $39 \%$ & $61 \%$ & $2 \%$ & $45 \%$ & $24 \%$ & $2 \%$ & $27 \%$ \\
\hline 9,1 ve üzeri & 64 & $42 \%$ & $58 \%$ & $52 \%$ & $48 \%$ & $14 \%$ & $86 \%$ & $75 \%$ & $25 \%$ & $55 \%$ & $45 \%$ & $0 \%$ & $42 \%$ & $22 \%$ & $13 \%$ & $23 \%$ \\
\hline Toplam & 218 & $40 \%$ & $60 \%$ & $41 \%$ & $59 \%$ & $6 \%$ & $94 \%$ & $69 \%$ & $31 \%$ & $44 \%$ & $56 \%$ & $3 \%$ & $42 \%$ & $27 \%$ & $8 \%$ & $20 \%$ \\
\hline \multicolumn{17}{|l|}{$\begin{array}{l}\text { Oda Ücret } \\
\text { Aralığı }\end{array}$} \\
\hline $500 \mathrm{TL}$ ve alt1 & 34 & $12 \%$ & $88 \%$ & $32 \%$ & $68 \%$ & $0 \%$ & $100 \%$ & $41 \%$ & $59 \%$ & $32 \%$ & $68 \%$ & $3 \%$ & $68 \%$ & $18 \%$ & $0 \%$ & $12 \%$ \\
\hline 501TL- 1000TL & 54 & $35 \%$ & $65 \%$ & $41 \%$ & $59 \%$ & $0 \%$ & $100 \%$ & $57 \%$ & $43 \%$ & $43 \%$ & $57 \%$ & $7 \%$ & $39 \%$ & $37 \%$ & $11 \%$ & $6 \%$ \\
\hline $1001 \mathrm{TL}-1500 \mathrm{TL}$ & 34 & $24 \%$ & $76 \%$ & $29 \%$ & $71 \%$ & $9 \%$ & $91 \%$ & $68 \%$ & $32 \%$ & $35 \%$ & $65 \%$ & $6 \%$ & $41 \%$ & $24 \%$ & $9 \%$ & $21 \%$ \\
\hline $1501 \mathrm{TL}-2000 \mathrm{TL}$ & 38 & $58 \%$ & $42 \%$ & $66 \%$ & $34 \%$ & $11 \%$ & $89 \%$ & $87 \%$ & $13 \%$ & $66 \%$ & $34 \%$ & $0 \%$ & $39 \%$ & $13 \%$ & $0 \%$ & $47 \%$ \\
\hline 2000TL ve üzeri & 58 & $60 \%$ & $40 \%$ & $38 \%$ & $62 \%$ & $9 \%$ & $91 \%$ & $86 \%$ & $14 \%$ & $41 \%$ & $59 \%$ & $0 \%$ & $33 \%$ & $33 \%$ & $14 \%$ & $21 \%$ \\
\hline Toplam & 218 & $40 \%$ & $60 \%$ & $41 \%$ & $59 \%$ & $6 \%$ & $94 \%$ & $69 \%$ & $31 \%$ & $44 \%$ & $56 \%$ & $3 \%$ & $42 \%$ & $27 \%$ & $8 \%$ & $20 \%$ \\
\hline \multicolumn{17}{|l|}{ İșletme Tipi } \\
\hline Sahil & 136 & $54 \%$ & $46 \%$ & $43 \%$ & $57 \%$ & $9 \%$ & $91 \%$ & $77 \%$ & $23 \%$ & $46 \%$ & $54 \%$ & $1 \%$ & $35 \%$ & $30 \%$ & $9 \%$ & $25 \%$ \\
\hline Șehir & 73 & $18 \%$ & $82 \%$ & $38 \%$ & $62 \%$ & $0 \%$ & $100 \%$ & $55 \%$ & $45 \%$ & $40 \%$ & $60 \%$ & $7 \%$ & $53 \%$ & $21 \%$ & $5 \%$ & $14 \%$ \\
\hline Diğer & 9 & $22 \%$ & $78 \%$ & $44 \%$ & $56 \%$ & $0 \%$ & $100 \%$ & $67 \%$ & $33 \%$ & $44 \%$ & $56 \%$ & $0 \%$ & $67 \%$ & $22 \%$ & $11 \%$ & $0 \%$ \\
\hline Toplam & 218 & $40 \%$ & $60 \%$ & $41 \%$ & $59 \%$ & $6 \%$ & $94 \%$ & $69 \%$ & $31 \%$ & $44 \%$ & $56 \%$ & $3 \%$ & $42 \%$ & $27 \%$ & $8 \%$ & $20 \%$ \\
\hline \multicolumn{17}{|l|}{ Calışma Süresi } \\
\hline Sezonluk & 131 & $56 \%$ & $44 \%$ & $43 \%$ & $57 \%$ & $9 \%$ & $91 \%$ & $78 \%$ & $22 \%$ & $44 \%$ & $56 \%$ & $0 \%$ & $35 \%$ & $31 \%$ & $9 \%$ & $24 \%$ \\
\hline Yılllk & 87 & $17 \%$ & $83 \%$ & $39 \%$ & $61 \%$ & $0 \%$ & $100 \%$ & $56 \%$ & $44 \%$ & $43 \%$ & $57 \%$ & $8 \%$ & $53 \%$ & $20 \%$ & $6 \%$ & $14 \%$ \\
\hline Toplam & 218 & $40 \%$ & $60 \%$ & $41 \%$ & $59 \%$ & $6 \%$ & $94 \%$ & $69 \%$ & $31 \%$ & $44 \%$ & $56 \%$ & $3 \%$ & $42 \%$ & $27 \%$ & $8 \%$ & $20 \%$ \\
\hline \multicolumn{17}{|l|}{ İș Pozisyonu } \\
\hline Barlar & 11 & $64 \%$ & $36 \%$ & $45 \%$ & $55 \%$ & $18 \%$ & $82 \%$ & $82 \%$ & $18 \%$ & $45 \%$ & $55 \%$ & $9 \%$ & $9 \%$ & $36 \%$ & $9 \%$ & $36 \%$ \\
\hline Kat hizmetleri & 26 & $31 \%$ & $69 \%$ & $42 \%$ & $58 \%$ & $15 \%$ & $85 \%$ & $73 \%$ & $27 \%$ & $46 \%$ & $54 \%$ & $0 \%$ & $65 \%$ & $19 \%$ & $8 \%$ & $8 \%$ \\
\hline Mutfak & 49 & $29 \%$ & $71 \%$ & $45 \%$ & $55 \%$ & $2 \%$ & $98 \%$ & $65 \%$ & $35 \%$ & $49 \%$ & $51 \%$ & $0 \%$ & $55 \%$ & $18 \%$ & $4 \%$ & $22 \%$ \\
\hline Önbüro & 88 & $41 \%$ & $59 \%$ & $34 \%$ & $66 \%$ & $1 \%$ & $99 \%$ & $66 \%$ & $34 \%$ & $36 \%$ & $64 \%$ & $6 \%$ & $34 \%$ & $35 \%$ & $8 \%$ & $17 \%$ \\
\hline Servis & 44 & $52 \%$ & $48 \%$ & $50 \%$ & $50 \%$ & $9 \%$ & $91 \%$ & $75 \%$ & $25 \%$ & $50 \%$ & $50 \%$ & $2 \%$ & $39 \%$ & $20 \%$ & $11 \%$ & $27 \%$ \\
\hline Toplam & 218 & $40 \%$ & $60 \%$ & $41 \%$ & $59 \%$ & $6 \%$ & $94 \%$ & $69 \%$ & $31 \%$ & $44 \%$ & $56 \%$ & $3 \%$ & $42 \%$ & $27 \%$ & $8 \%$ & $20 \%$ \\
\hline
\end{tabular}

Tablo 1'de görüldüğü gibi elde edilen genel veriler öncelikle 8 ana başlık altında incelenmiştir. Bu başlıklar; otel yıldız sayısı, otel sahiplik durumu, pansiyon tipi, Trivago puanı, oda ücret aralığı, 
işletme tipi, çalışma tipi ve iş pozisyonudur. Bu başlıklara göre elde edilen bulgular aşağıda yer almaktadır.

\section{Otel yuldiz sayısına göre bulgular}

İçerik analizi sonucu elde edilen verilerden oluşturulan Tablo 1'e bakıldığında otellerin yıldız sayısına göre ilanda kullandıkları kelime sayısı bakımından sadece 5 yıldızlı otellerin iş ilanlarında 201 ve üzeri kelime kullandığı görülmektedir. 201 ve üzeri kelime kullananların oranı \%24'tür. Genel olarak otellerin $\% 42$ 'si ise iş ilanlarında 51 ve 100 arasında kelime kullanmıştır. Bu sonuçlara göre 5 yıldızlı konaklama işletmelerinin iş ilanlarında işin içeriği ile ilgili daha fazla bilgi miktarına yer verdiği söylenebilir.

Otellerin yıldız sayısına göre ilanda görsel (logo, fotoğraf, video vb.) kullanma oranları incelendiğinde 5 yıldızlı otellerin \%73'ü ilanda görsel kullanmıştır. Aynı göstergeler Tablo 1'de ortaya çıkan ilanda adaya sağlanacak sosyal imkanlar/yan haklar bilgisinin olup olmaması incelendiğinde sadece 5 yıldızlı otellerde bu bilginin yer almasını da açıklayabilir.

Otellerin yıldız sayısına göre kullanılan ilan diline bakıldığında 5 yıldızlı otellerin iş ilanlarının \%16'sının, 4 yıldızlı otellerin ise \%9'unun ilan dilinin İngilizce olduğu görülmektedir. Bu sonuç işletmenin bulunduğu konum, çalıştığı turizm pazarı ve yabanc1 müşteri ağırlığına göre değişmekle birlikte, ilan verilen pozisyonda yabancı dil ihtiyacının olup olmamasına göre de farklılık gösterebilmektedir. Tüm müşterileri yabancı olan bir işletmede mutfak departmanında bulaşıkçı olarak çalışacak bir personel müşteri ile minimum iletişimde olacağından, bu personelden yabancı dil bilmesi beklenmemektedir.

\section{Otel sahiplik durumuna göre bulgular}

Otel sahipliği açısından bakıldığında yabancılara ait otellerin \%50'si iş ilanında 201 ve üzeri kelime kullanmıştır. Yine yabancıların sahip olduğu otellerin $\% 72$ si iş ilanında görsel (logo, fotoğraf, video vb.) kullanmaktadır. Bu oran yerli otellerde $\% 69$, ortaklık şeklindeki otellerde \%70'tir. Sahipliği ortaklık şeklinde olan otellerin \%65'nin iş ilanında iş tanımı yer almaktadır. Bu oran yabancı otellerde $\% 56$, yerli otellerde $\% 38$ 'dir.

\section{Pansiyon tipine göre bulgular}

Çalışmada incelenen ilanlara ait işletmelerin çeşitli pansiyon tiplerinde çalıştıkları görülmüştür. $\mathrm{Bu}$ pansiyon tipleri: her şey dahil, oda kahvaltı, tam pansiyon, yarım pansiyon ve sadece oda olarak yer almaktadır. Bazı işletmeler ürün çeşitlendirmesi amacıyla çeşitli pansiyon tiplerinde satış da yapabilmektedir. Çoğu işletme ise tek pansiyon tipinde çalışmaktadır. Bu sebeple pansiyon tipleri belirlenirken işletmenin satış yaptığı en yüksek pansiyon tipi göz önüne alınmıştır.

Otellerin pansiyon tiplerine göre iş ilanlarında kullandıkları kelime sayısına bakıldığında oda kahvaltı olarak hizmet veren otellerin \%34'ü ilanda 201 ve üzeri kelime kullanmıştır. Ayrıca oda kahvaltı hizmet veren otellerin $\% 65$ 'nin iş ilanında iş tanımı yer almaktadır. Pansiyon tipine göre otellerin toplamda $\% 40$ 'ında iş ilanlarında işletme ile ilgili detaylı bilgi yer almaktadır. Oda kahvaltı hizmet veren otellerde bu oran \%59'dur. Yine oda kahvaltı hizmet veren otellerin \%80'ninin iş ilanında görsel (logo, fotoğraf, video vb.) yer almaktadır. Genel nitelikler ve iş tanımının ayrı ayrı belirtilip belirtilmediği incelendiğinde, pansiyon tipine göre otellerin iş ilanlarında oda kahvaltı hizmet veren otellerin $\% 65$ 'inde bu ayrım belirtilmiştir.

\section{Trivago puanına göre bulgular}

Genel olarak tüketiciler ürünleri satın almadan önce beş duyu organı ile duyumsayarak algılamak ve anlamak isterler. Koç'a (2012) göre "daha fazla duyuya hitap eden ve daha fazla çeşitte uyarana dayanarak nesneleri algılamaya çalışmak ve bunun sonucunda tutum ve davranış geliştirmedeki amaç, tüketicilerin algılanan risk miktarını azaltmak ve ihtiyaçları en iyi karşılayan çözümü bulma çabasından kaynaklanmaktadır". Hizmetlerin soyutluk özelliğinden dolayı duyumsayarak algılanması çok mümkün değildir. Ancak hizmetleri görsel olarak algilamak mümkün olabilmektedir. Bu anlamda konaklama işletmelerinin puanları müşterinin algılanan riski azaltması için önemli bir kriterdir. 
Birçok sektörde tüketiciler, satın aldıkları ürün veya hizmeti bazen de ilgili firmaları, alışveriş memnuniyet seviyesi veya ilgili sektöre ait çeşitli kriterlere göre puanlamaktadır. Birçok tüketici de ilgili ürün veya hizmeti almadan önce bu yorumları inceleyerek satın alıp almama kararını verebilmektedir. Çevrimiçi ortamlarda paylaşılan tüketici görüşleri, otel rezervasyonu yaptırırken potansiyel tüketicilerin karar verme ve satın alma davranışlarını doğrudan etkilmektedir (Saçkes ve Doğdubay, 2019). Bu çalışmada Trivago sitesinde yer alan işletme puanları kullanılmıştır. İşletmelerin puanları $(7,5$ ve altı) $(7,6$ - 8,0) $(8,1-8,5)(8,6$ - 9,0) $(9,1$ ve üzeri) şeklinde 5 gruba ayrılmıştır. 9,1 ve üzeri puan alan otellerin \%55'inin ilanında iş tanımı ayrı olarak belirtilmiştir. Yine 9,1 ve üzeri puan otellerin \%75'inin iş ilanında görsel (logo, fotoğraf, video vb.) yer almaktadır.

İlanda yer alan kelime sayısı incelendiğinde iş ilanında en fazla 201 ve üzeri kelimeyi en fazla kullanan oteller 8,6 - 9,0 arası puana sahip otellerdir. Puan aralığı yüksek olan işletmelerin iş ilanlarında daha fazla kelime kullandıkları tespit edilmiştir. Böyle bir sonucun, konaklama işletmelerinin Trivago vb. platformlarda daha yüksek müşteri puanı elde edebilmek için nitelikli bir işgören kadrosuna sahip olmaları gerektiğinin farkında olmalarından, bu sebeple de iş ilanlarını daha ayrıntılı hazırlama yönünde çaba sarf etmelerinden kaynaklandığg düşünülmektedir.

\section{Oda ücret aralı̆̆ına göre bulgular}

İçerik analizinde yer alan işletmelere ait oda ücreti en düşük gecelik oda ücreti baz alınarak kullanılmıştır. Farklı sitelerde farklı oda ücreti olması sebebiyle sırasıyla hotels.com, odamax.com ve setur.com sitelerindeki fiyatlar baz alınmıştır. Birden fazla siteden kontrol edilmesinin sebebi ise her işletmenin her site ile anlaşmasının olmamasından dolayıdır. Sıralamaya göre fiyat bulunan ilk siteden edinilen fiyatlar kullanılmıştır.

Oteller günlük oda ücretlerine göre incelendiğinde ise 1501 - 2000 TL fiyat aralığındaki otellerin iş ilanında kullandığı kelime sayıları diğer fiyat aralığındaki otellere göre belirgin farklılık göstermektedir. Oda fiyatı 1501-2000 TL arasındaki otellerin \%47'si iş ilanında 201 ve üzeri kelime kullanmakta ve \%66'sının iş ilanında iş tanımı yer almaktadır. Ayrıca 1501-2000 TL arasında oda ücreti olan otellerin \%87'sinin iş ilanında görsel (logo, fotoğraf, video vb.) yer almaktadır. Çünkü yüksek fiyat yüksek değer beklentisi oluşturmaktadır. Yani müşteri yüksek fiyatlı bir oteli tercih ettiğinde yüksek değer görmek istemektedir. Bu sebeple de konaklama işletmelerinin müşterilere yükssek değer sunabilmesi için asıl ürün olan hizmet ürününü üreten eleman seçiminde daha fazla çabaya girmesi ve çok dikkatli davranması beklenebilir.

\section{Işsletme tipine göre bulgular}

Konaklama işletmeleri Türkiye'de yaygın olarak fiziki konumuna göre şehir oteli ve tatil amaçlı sahil oteli olarak sınıflandırılabilmektedir. Bunun haricinde de işletmeler tematik olarak farklı konseptlerde hizmet verse de sayıları oldukça azdır. İş ilanlarının otel türlerine göre dağılımında sahil otellerinin fazla olması dikkat çekicidir. Çalı̧̧mada yer alan işletmeler çalışma şekline göre ayrılıp ilan kriterleri incelendiğinde sahil otellerinin $\% 25$ 'i iş ilanında 201 ve üzeri kelime kullandığ 1 ve bu otellerin iş ilanlarının \%46'sında iş tanımının yer aldığı görülmektedir. Ayrıca sahil otellerinin \%77'si iş ilanında görsel (logo, fotoğraf, video vb.) kullandığı ve \%54'ü iş ilanlarında işletmeleri ile ilgili detaylı bilgiye yer verdiği görülmektedir. Sahil otelleri şehir otellerine göre daha uzun süre konaklayan ve yaygın şekilde yabancı turist ağırlayan işletmelerdir. Genellikle günübirlik konaklama ihtiyacına hitap eden şehir otellerinde ise müşteri ile kısa süreli iletişim ve müşterinin işletmede bulunma süresinin azlığ gibi etmenler, işletmelerin daha az personel ile faaliyet göstermesine neden olmaktadır. Bunun aksine sahil otellerinde ise müş̧erinin hem işletmede geçirdiği süre hem de faydalandığ 1 hizmetler daha fazla olduğundan bu hizmetleri sunacak daha fazla personele ihtiyaç duyulmaktadır. Müşteri ve müşteriyi gönderen uluslararası acentaların memnuniyeti de bu aşamada hizmeti sunan personel ile ilgilidir. $\mathrm{Bu}$ sebeple müşteri ile etkileşimin yoğun olduğu işletmelerin iş ilanlarında daha fazla kritere dikkat ettiği söylenebilir.

\section{İşletmelerin çalışma süresine göre bulgular}

Konaklama işletmeleri hizmetlerini bölgesel koşullar ve coğrafi koşullara göre yılın tamamında veya belli bir kısmında verebilmektedir. Bu durum işletmelerin sezonluk veya tüm yıl çalışma şeklinde ayırt 
edilebilmesine olanak sağlar. Sezonluk işletmeler mevsimsel koşullara göre sadece belli aylarda hizmet verip yılın kalan aylarında kapalı kalmaktadır.

Çalışmada incelenen işletmelerin çalışma sürelerine göre iş ilanları kriterleri incelendiğinde sezonluk faaliyet gösteren oteller tüm yıl faaliyet gösteren otellere göre iş ilanlarında daha çok kelime kullanmaktadır. Belirli dönemlerde hizmet verecek olan sezonluk oteller bu süre içinde personel yetiştirmek yerine, istediği kriterlere uygun personeli bulmak için iş ilanlarında daha çok ayrıntıya yer vermektedir. Ayrıca sezonluk otellerin \%78'inin iş ilanlarında görsel (logo, fotoğraf, video vb.) bulunmaktadir.

\section{İs pozisyonuna göre bulgular}

Konaklama işletmeleri verdiği hizmetin kompleks yapısı gereği tüm departmanlar aynı anda çalışmaktadır. $\mathrm{Bu}$ sebeple konaklama işletmeleri uzmanlığ duymaktadır. İncelenen iş ilanlarının pozisyonlara göre dağılımına bakıldığında en fazla önbüro, mutfak ve servis birimlerinde elemana ihtiyaç duyulduğu görülmektedir. Erdem ve Gezen (2014) çalışmalarında da benzer sonuçlara ulaşmışlardır. Erdem ve Gezen (2014) inceledikleri iş ilanlarında en fazla önbüro, yiyecek-içecek ve kat hizmetleri elemanına ihtiyaç olduğu sonucuna ulaşmışlardır. Çünkü bu birimler konaklama işletmelerinde en fazla işgörene ihtiyaç duyulan birimlerdir.

Ayrıca bu birimler, konaklama işletmelerinin temel bölümleri arasında yer alan ve işletmelere doğrudan gelir getiren (özellikle önbüro ve yiyecek-içecek) bölümlerdendir (Batman, 1999:117-118). İlanlar incelenirken başvuru pozisyonlarına göre departmanlara ayrılarak değerlendirilmiştir. $\mathrm{Bu}$ aşamada dikkat çeken bulgu ise bar, mutfak ve servis departmanları için eleman arayan oteller kat hizmetleri ve önbüro departmanları için eleman arayan otellere göre iş ilanlarında daha fazla 201 ve üzeri kelime kullanmış olmalarıdır.

Yukarıda incelenen başlıklar haricinde, işletmelerin kendi kategorileri içindeki özellikleri ile ilan kriterleri de ayrıntılı incelendiğinde dikkat çeken bazı önemli bulgulara rastlanmıştır. Araştırmada sayısal çoğunlukta bulunan 5 yıldızlı işletmelerin yapısal özelliklerine göre bazı ilan kriterlerinde ortaya çıkan bulgular aşağıda tablolar halinde sıralanmıştır.

Tablo 2: 5 yıldızlı otel işletmelerinin pansiyon tipine göre ilanda kullanılan kelime miktarı

\begin{tabular}{|c|c|c|c|c|c|c|}
\hline \multirow{2}{*}{ Pansiyon Tipi } & \multirow{2}{*}{ İşletme sayısı } & \multicolumn{5}{|c|}{ Kelime Sayısı } \\
\cline { 3 - 6 } & & $\mathbf{1 0 - 5 0}$ & $\mathbf{5 1 - 1 0 0}$ & $\mathbf{1 0 1 - 1 5 0}$ & $\mathbf{1 5 1 - 2 0 0}$ & $\mathbf{2 0 1}$ ve üzeri \\
\hline Her şey Dahil & 59 & & $42 \%$ & $34 \%$ & $12 \%$ & $12 \%$ \\
\hline Oda kahvaltı & 62 & $2 \%$ & $19 \%$ & $29 \%$ & $6 \%$ & $44 \%$ \\
\hline Tam pansiyon & 7 & & $57 \%$ & $29 \%$ & & $14 \%$ \\
\hline Yarım Pansiyon & 2 & & $50 \%$ & $50 \%$ & & $14 \%$ \\
\hline Sadece oda & 42 & $7 \%$ & $57 \%$ & $17 \%$ & $5 \%$ & $24 \%$ \\
\hline Toplam & 172 & $2 \%$ & $38 \%$ & $28 \%$ & $8 \%$ & \\
\hline
\end{tabular}

Tablo 2'de göze çarpan önemli detay oda kahvaltı hizmet veren 5 y1ldızlı otel işletmelerinin neredeyse yarısı ilanlarında 201 ve üzeri kelime kullanmıştır. Yine 201 ve üzeri kelime kullanımında en düşük oran ise her şey dahil sisteminde hizmet veren otellerdir. Feldman vd. (2006) iş ilanında ayrıntılı bilgi sunmanın, iş ilanının inandırıcılığı ve bilgilendirme düzeyi, iş ilanına yönelik tutum ve örgüte yönelik tutum üzerinde anlamlı bir etkisi olduğunu bulmuşlardır. Ayrıca yine aynı çalışmada ayrıntılı bilgi içeren iş ilanlarının, adayların ilana başvuru yapma niyetini de artırdığı sonucuna ulaşmışlardır. 
Tablo 3: 5 yıldızlı otel işletmelerinin oda sayısına göre ilanda kullanılan kelime miktarı

\begin{tabular}{|c|c|c|c|c|c|c|}
\hline \multirow{2}{*}{ Oda Sayısı } & \multirow{2}{*}{ İşletme sayısı } & \multicolumn{5}{|c|}{ Kelime Sayısı } \\
\cline { 3 - 7 } & & $\mathbf{1 0 - 5 0}$ & $\mathbf{5 1 - 1 0 0}$ & $\mathbf{1 0 1 - 1 5 0}$ & $\mathbf{1 5 1 - 2 0 0}$ & $\mathbf{2 0 1}$ ve üzeri \\
\hline $1-50$ & 3 & & & & & $100 \%$ \\
\hline $51-150$ & 56 & $4 \%$ & $11 \%$ & $36 \%$ & $11 \%$ & $39 \%$ \\
\hline $151-250$ & 31 & $6 \%$ & $65 \%$ & $13 \%$ & & $16 \%$ \\
\hline $251-400$ & 39 & & $33 \%$ & $41 \%$ & $15 \%$ & $10 \%$ \\
\hline 401 ve üzeri & 43 & & $63 \%$ & $19 \%$ & $2 \%$ & $16 \%$ \\
\hline Toplam & 172 & $2 \%$ & $38 \%$ & $28 \%$ & $8 \%$ & $24 \%$ \\
\hline
\end{tabular}

150 ve altında oda sayısına sahip 5 yıldızlı otel işletmelerinin neredeyse yarısı ilanlarında 201 ve üzeri kelime kullanmıştır. Daha yüksek oda sayısına sahip otel işletmelerinin çoğunluğunda ise kelime sayısı 50 ila 150 arasında değişmektedir. Yıldız kategorisinde aynı standartta olmasına rağmen oda sayısı az olan işletmelerin ilanlarını daha fazla detaylandırdığı söylenebilir.

Tablo 4: 5 yıldızlı otel işletmelerinin sahipliğe göre ilanda kullanılan kelime miktarı

\begin{tabular}{|c|c|c|c|c|c|c|}
\hline \multirow{2}{*}{ Sahiplik } & \multirow{2}{*}{ İşletme sayısı } & \multicolumn{5}{|c|}{ Kelime Sayısı } \\
\cline { 3 - 6 } & & $\mathbf{1 0 - 5 0}$ & $\mathbf{5 1 - 1 0 0}$ & $\mathbf{1 0 1 - 1 5 0}$ & $\mathbf{1 5 1 - 2 0 0}$ & $\mathbf{2 0 1}$ ve üzeri \\
\hline Yerli & 27 & $4 \%$ & $26 \%$ & $7 \%$ & $4 \%$ & $59 \%$ \\
\hline Yabanc1 & 125 & $1 \%$ & $39 \%$ & $34 \%$ & $9 \%$ & $17 \%$ \\
\hline Ortakl1k & 20 & $10 \%$ & $50 \%$ & $15 \%$ & $5 \%$ & $20 \%$ \\
\hline Toplam & 172 & $2 \%$ & $38 \%$ & $28 \%$ & $8 \%$ & $24 \%$ \\
\hline
\end{tabular}

İşletme sahipliği bakımından 5 yıldızlı otel işletmelerinin ilanlarında kullandığı kelime sayısında ise yerli işletmelerin ilanlarındaki 201 ve üzeri kelime kullanım sayısının oranı yabancı ve ortaklık sahibi işletmelerden 3 kat fazla olduğu görülmektedir. Yabancı ve ortaklık sahibi olan işletmelerin kelime sayıs1 ise 51 ila 100 arasındadır.

Tablo 5: 5 yıldızlı otel işletmelerinin oda ücretine göre ilanda kullanılan kelime miktarı

\begin{tabular}{|c|c|c|c|c|c|c|}
\hline Standart oda ücreti & \multirow{2}{*}{ İşletme sayısı } & \multicolumn{5}{|c|}{ Kelime Sayıs } \\
\cline { 3 - 6 } & & $\mathbf{1 0 - 5 0}$ & $\mathbf{5 1 - 1 0 0}$ & $\mathbf{1 0 1 - 1 5 0}$ & $\mathbf{1 5 1 - 2 0 0}$ & $\mathbf{2 0 1}$ ve üzeri \\
\hline 500 tl ve altı & 22 & $5 \%$ & $73 \%$ & $14 \%$ & & $9 \%$ \\
\hline $501-1000$ & 32 & $9 \%$ & $31 \%$ & $44 \%$ & $9 \%$ & $6 \%$ \\
\hline $1001-1500$ & 27 & & $37 \%$ & $30 \%$ & $7 \%$ & $26 \%$ \\
\hline $1501-2000$ & 35 & & $37 \%$ & $11 \%$ & & $51 \%$ \\
\hline 2000 ve üzeri & 56 & & $30 \%$ & $34 \%$ & $14 \%$ & $21 \%$ \\
\hline Toplam & 172 & $2 \%$ & $38 \%$ & $28 \%$ & $8 \%$ & $24 \%$ \\
\hline
\end{tabular}

İşletmelerin fiyat aralıklarına göre gruplandığı tabloda ise 1501 ila $2000 \mathrm{TL}$ arası günlük oda fiyatına sahip işletmelerin, diğer fiyat gruplarındaki işletmelerden belirgin şekilde daha fazla kelime kullandıkları görülmektedir. Yine tabloda dikkat çeken bir diğer husus ise $500 \mathrm{TL}$ ve altı günlük oda fiyatına sahip işletmelerin \%73’ü 51 ila 100 kelime kullanıyor olmasıdır. 
Tablo 6: 5 yıldızlı otel işletmelerin ilan pozisyonuna göre ilanda kullanılan kelime miktarı

\begin{tabular}{|c|c|c|c|c|c|c|}
\hline \multirow{2}{*}{ Pozisyon } & \multirow{2}{*}{ İşletme sayısı } & \multicolumn{5}{|c|}{ Kelime Sayısı } \\
\cline { 3 - 7 } & & $\mathbf{1 0 - 5 0}$ & $\mathbf{5 1 - 1 0 0}$ & $\mathbf{1 0 1 - 1 5 0}$ & $\mathbf{1 5 1 - 2 0 0}$ & $\mathbf{2 0 1}$ ve üzeri \\
\hline Barlar & 10 & $10 \%$ & $10 \%$ & $30 \%$ & $10 \%$ & $40 \%$ \\
\hline Kat hizmetleri & 19 & & $68 \%$ & $21 \%$ & & $11 \%$ \\
\hline Mutfak & 40 & & $50 \%$ & $20 \%$ & $5 \%$ & $25 \%$ \\
\hline Önbüro & 64 & $3 \%$ & $30 \%$ & $38 \%$ & $9 \%$ & $20 \%$ \\
\hline Servis & 39 & $3 \%$ & $33 \%$ & $23 \%$ & $10 \%$ & $31 \%$ \\
\hline Toplam & 172 & $2 \%$ & $38 \%$ & $28 \%$ & $8 \%$ & $24 \%$ \\
\hline
\end{tabular}

5 yıldızlı otel işletmelerinin ilan verdiği pozisyonlara ait departmanların ilan kelime sayılarına bakıldığında; bar için verilen ilanların \%40'ı 201 ve daha fazla kelimeye sahip ilanlar olduğu görülmektedir. Kat hizmetleri departmanında ise \%68'lik bir oranla 51 ila 100 kelime arasından kullanıldığı görülmektedir. Benzer şekilde Mutfak departmanı için bu oran \%50'dir.

Tablo 7: 5 yıldızlı otel işletmelerinde başvuru pozisyonuna göre genel nitelikler ve iş tanımının ayrı ayrı belirtilip belirtilmediği bilgisi

\begin{tabular}{|c|c|c|c|c|}
\hline Departman & Pansiyon Tipi & İşletme sayısı & Belirtilmiş & Belirtilmemiş \\
\hline \multirow[t]{4}{*}{ Barlar } & Her şey Dahil & 10 & $33 \%$ & $67 \%$ \\
\hline & Oda kahvaltı & 2 & $100 \%$ & \\
\hline & Tam pansiyon & 2 & & $100 \%$ \\
\hline & Sadece oda & 2 & & $100 \%$ \\
\hline Barlar Toplam & & 16 & $40 \%$ & $60 \%$ \\
\hline \multirow[t]{4}{*}{ Kat hizmetleri } & Her şey Dahil & 15 & $33 \%$ & $67 \%$ \\
\hline & Oda kahvaltı & 5 & $75 \%$ & $25 \%$ \\
\hline & Yarım Pansiyon & 2 & & $100 \%$ \\
\hline & Sadece oda & 8 & $40 \%$ & $60 \%$ \\
\hline Kat hizmetleri Toplam & & 30 & $42 \%$ & $58 \%$ \\
\hline \multirow[t]{5}{*}{ Mutfak } & Her şey Dahil & 14 & & $100 \%$ \\
\hline & Oda kahvaltı & 21 & $83 \%$ & $17 \%$ \\
\hline & Tam pansiyon & 7 & $25 \%$ & $75 \%$ \\
\hline & Yarım Pansiyon & 2 & & $100 \%$ \\
\hline & Sadece oda & 16 & $40 \%$ & $60 \%$ \\
\hline Mutfak Toplam & & 60 & $50 \%$ & $50 \%$ \\
\hline \multirow[t]{4}{*}{ Önbüro } & Her şey Dahil & 44 & $24 \%$ & $76 \%$ \\
\hline & Oda kahvaltı & 30 & $57 \%$ & $43 \%$ \\
\hline & Tam pansiyon & 2 & & $100 \%$ \\
\hline & Sadece oda & 29 & $29 \%$ & $71 \%$ \\
\hline Önbüro Toplam & & 105 & $36 \%$ & $64 \%$ \\
\hline \multirow[t]{4}{*}{ Servis } & Her şey Dahil & 20 & $33 \%$ & $67 \%$ \\
\hline & Oda kahvaltı & 22 & $71 \%$ & $29 \%$ \\
\hline & Tam pansiyon & 2 & & $100 \%$ \\
\hline & Sadece oda & 14 & $44 \%$ & $56 \%$ \\
\hline Servis Toplam & & 58 & $51 \%$ & $49 \%$ \\
\hline
\end{tabular}

5 yıldızlı işletmelerde departmanlar için verilen ilanlarda işletmelerin pansiyon tipine göre genel nitelikler ve iş tanımının ayrı ayrı belirtilip belirtilmediği incelendiğinde önemli bir husus göze 
çarpmaktadır. Servis, mutfak ve kat hizmetleri departmanlarına ait pozisyonların oda kahvaltı hizmet veren 5 yıldızlı otellerin ilanlarının \%70' den fazlasında genel nitelikler ve iş tanımı ayrı ayrı belirtilmiştir. Rynes ve Miller (1983) çalışmalarında, iş ilanında iş tanımı ve işin genel özelliklerine ilişkin bilgi vermenin firma çekiciliğini arttırdığını ve iş arayanların işletme ile ilgili algılarını olumlu şekilde etkilediğini ortaya koymuşlarıdır.

Tablo 8: 5 yıldılı otel işletmelerinde pansiyon tipine göre ilanda görsel bulunması (logo, fotoğraf, video $\mathrm{vb}$.)

\begin{tabular}{|c|c|c|c|}
\hline Pansiyon Tipi & İşletme sayısı & \multicolumn{2}{|c|}{ İlanda Görsel Bulunması } \\
\cline { 3 - 4 } & & Bulunuyor & Bulunmuyor \\
\hline Her şey Dahil & 59 & $75 \%$ & $25 \%$ \\
\hline Oda kahvaltı & 62 & $87 \%$ & $13 \%$ \\
\hline Tam pansiyon & 7 & $57 \%$ & $43 \%$ \\
\hline Yarım Pansiyon & 2 & & $100 \%$ \\
\hline Sadece oda & 42 & $57 \%$ & $43 \%$ \\
\hline
\end{tabular}

Tabloda 5 yıldızlı işletmelerin pansiyon tipine göre ilanlarında görsel bulunma oranı oda kahvaltı hizmet veren işletmelerde en yüksek olarak görülmektedir. Hemen ardından ise her şey dahil sistem çalışan işletmeler gelmektedir.

Son olarak araştırmada ele alınan tüm işletmeler hizmet verdiği pansiyon tipi açısından incelendiğinde, iş ilanı verilen pozisyona ait departmanlara göre ilandaki kelime sayıları tespit edilerek Tablo 9'da sunulmuştur.

Tablo 9: Pansiyon tipi ve pozisyona göre ilanda kullanılan kelime miktarı

\begin{tabular}{|c|c|c|c|c|c|c|c|}
\hline \multirow[b]{2}{*}{ Pansiyon Tipi } & \multirow[b]{2}{*}{ Pozisyon } & \multirow[b]{2}{*}{ İşletme sayısı } & \multicolumn{5}{|c|}{ Kelime Sayısı } \\
\hline & & & $10-50$ & $51-100$ & 101-150 & 151-200 & $\begin{array}{c}201 \text { ve } \\
\text { üzeri }\end{array}$ \\
\hline \multirow[t]{5}{*}{ Her şey Dahil } & Barlar & 6 & $0 \%$ & $17 \%$ & $33 \%$ & $17 \%$ & $33 \%$ \\
\hline & Kat hizmetleri & 9 & $0 \%$ & $67 \%$ & $33 \%$ & $0 \%$ & $0 \%$ \\
\hline & Mutfak & 10 & $0 \%$ & $80 \%$ & $10 \%$ & $0 \%$ & $10 \%$ \\
\hline & Önbüro & 30 & $0 \%$ & $43 \%$ & $37 \%$ & $17 \%$ & $3 \%$ \\
\hline & Servis & 13 & $0 \%$ & $38 \%$ & $23 \%$ & $15 \%$ & $23 \%$ \\
\hline \multirow[t]{5}{*}{ Oda kahvaltı } & Barlar & 3 & $0 \%$ & $0 \%$ & $33 \%$ & $0 \%$ & $67 \%$ \\
\hline & Kat hizmetleri & 6 & $0 \%$ & $50 \%$ & $33 \%$ & $0 \%$ & $17 \%$ \\
\hline & Mutfak & 21 & $0 \%$ & $43 \%$ & $14 \%$ & $10 \%$ & $33 \%$ \\
\hline & Önbüro & 31 & $6 \%$ & $13 \%$ & $45 \%$ & $6 \%$ & $29 \%$ \\
\hline & Servis & 19 & $0 \%$ & $26 \%$ & $26 \%$ & $5 \%$ & $42 \%$ \\
\hline \multirow[t]{4}{*}{ Tam pansiyon } & Barlar & 1 & $0 \%$ & $0 \%$ & $100 \%$ & $0 \%$ & $0 \%$ \\
\hline & Mutfak & 4 & $0 \%$ & $50 \%$ & $25 \%$ & $0 \%$ & $25 \%$ \\
\hline & Önbüro & 3 & $67 \%$ & $33 \%$ & $0 \%$ & $0 \%$ & $0 \%$ \\
\hline & Servis & 1 & $0 \%$ & $100 \%$ & $0 \%$ & $0 \%$ & $0 \%$ \\
\hline \multirow[t]{3}{*}{ Yarım Pansiyon } & Kat hizmetleri & 2 & $0 \%$ & $100 \%$ & $0 \%$ & $0 \%$ & $0 \%$ \\
\hline & Mutfak & 1 & $0 \%$ & $0 \%$ & $100 \%$ & $0 \%$ & $0 \%$ \\
\hline & Önbüro & 1 & $0 \%$ & $0 \%$ & $100 \%$ & $0 \%$ & $0 \%$ \\
\hline \multirow[t]{5}{*}{ Sadece oda } & Barlar & 1 & $100 \%$ & $0 \%$ & $0 \%$ & $0 \%$ & $0 \%$ \\
\hline & Kat hizmetleri & 9 & $0 \%$ & $67 \%$ & $0 \%$ & $22 \%$ & $11 \%$ \\
\hline & Mutfak & 13 & $0 \%$ & $62 \%$ & $23 \%$ & $0 \%$ & $15 \%$ \\
\hline & Önbüro & 23 & $4 \%$ & $52 \%$ & $22 \%$ & $0 \%$ & $22 \%$ \\
\hline & Servis & 11 & $9 \%$ & $55 \%$ & $9 \%$ & $18 \%$ & $9 \%$ \\
\hline Genel Toplam & & 218 & $3 \%$ & $42 \%$ & $27 \%$ & $8 \%$ & $20 \%$ \\
\hline
\end{tabular}


İşletmelerin pansiyon tiplerine göre ilan verdikleri pozisyonlara ait departmanlara bakıldığında ise her şey dahil sistemde çalışan işletmelerin kat hizmetleri ve mutfak departmanları için verilen ilanlarda 50 ila 100 kelime kullanmış olması dikkat çekicidir. Diğer bir önemli husus ise oda kahvaltı çalışan işletmelerde barlar ve servis departmanı için verilen ilanların çoğunda 201 ve daha fazla kelime kullanılmasıdır. Genel olarak da bakıldığında oda kahvaltı hizmet veren işletmelerin \%34'ü, 201 ve üzeri kelime kullanmış, diğer pansiyon tiplerinde ise yoğunluğun 51 ila 100 kelime aralığında olduğu görülmüştür.

\section{Sonuç ve öneriler}

$\mathrm{Bu}$ çalışmada, turizm sektörü içinde yer alan konaklama işletmelerinin kariyer.net isimli internet sitesinde verdikleri iş ilanları incelenmiştir. İlanlarda yer alan kriterlere göre konaklama işletmelerinin iş ilanlarında amaca uygunluğu sağlayıp sağlayamadıklarını ortaya koymak amaçlanmıştır. Yoğun rekabetin yaşandığ 1 günümüz iş dünyasında birçok işletme için rekabet stratejilerindeki en önemli unsurlardan biri de insan kaynağıdır. Özellikle turizm gibi emek yoğun endüstrilerde, işgörenler ana kaynak olarak görülmektedir. Bu sebeple iş ilanları, turizm işletmeleri için doğru elemanı bulmak adına hayati öneme sahiptir. Bugün turizm işletmelerinin büyük bir kısmı iş ilanlarını internet üzerinden vermekte ve böylece geniş bir aday kitlesine ulaşmayı amaçlamaktadır.

İncelenen 218 iş ilanından 172 tanesi 5 yıldızlı oteller tarafından verilmiştir. 5 yıldızlı oteller diğer otellere göre iş ilanlarında daha fazla "kelime sayısı" (bilgi miktarı) ve "görsel" (logo, fotoğraf, video vb.) kullanmaktadır. Özellikle oda kahvaltı hizmet veren 5 yıldızlı otellerin iş ilanlarında daha fazla kelime ve görsel kullandığı söylenebilir. Bu sonuçlara göre 5 yıldızlı otellerin insan kaynakları süreçleri ve insan kaynakları yönetimi faaliyetlerinin daha gelişmiş olduğu, ayrıca işveren markası olma göstergelerinin temel düzeyde var olduğu söylenebilir. Yüce ve Highhouse (1998) çalışmalarında fazla bilgi içeren iş ilanlarının (bu bilgi ilan edilen işle çok fazla ilgili olmasa bile) diğer ilanlara göre daha çekici olduğu sonucuna ulaşmışlardır. İş ilanlarında yer alan önemli kriterlerden birisi de "iş tanımı" bilgisidir. İş tanımının varlığı, işin gerektirdiği niteliklere sahip doğru adaylara ulaşmak için çok önemlidir. İş tanımı sayesinde aday, çalışacağı departman ve işletme içinde nerede konumlanacağı, sahip olacağı sorumluluklar ve sınırlar hakkında bilgi sahibi olur. Ayrıca İK uzmanını ve yöneticileri zaman kaybından kurtarmaktadır. Bundan dolayı işletmelerin iş ilanlarında iş tanımına yer vermesi gereklidir. Araştırma sonuçlarına göre 218 adet iş ilanının \%44'ünde iş tanımı yer almaktadır. Basım ve diğerlerinin (2008) Türkiye ve İngiltere'deki gazetelerde yer alan iş ilanlarını inceledikleri çalışmalarında, Türkiye'deki iş ilanlarının çoğunluğunda; İngiltere'deki iş ilanlarının ise tamamında iş tanımı bilgisinin olduğu sonucuna ulaşmışlardır.

Oda fiyatları ile "kelime sayısı", "görsel kullanımı" ve "iş tanımı" arasındaki ilişki incelendiğinde; oda fiyat1 1501-2000 arasındaki otellerin diğer fiyatlara sahip otellere göre iş ilanlarında daha fazla "iş tanımı" bilgisine, kelime sayısına ve görsel kullanımına yer verdiği görülmektedir. Müssteri, yüksek fiyatlı bir oteli tercih ettiğinde yüksek değer görmek istemektedir. $\mathrm{Bu}$ sebeple de konaklama işletmelerinin müşterilere yüksek değer sunabilmesi için eleman seçiminde daha fazla çabaya girmesi, çok dikkatli davranması, elemana daha bütünsel bakması gerekmektedir. Ayrıca bu işletmelerin müşteri memnuniyetini sağlayabilmesi için öncelikle çalışanlarını mutlu etmesi de önemlidir. İş tanımı kadar "genel nitelikler" de iş ilanlarında önemli bir kriterdir. Genel nitelikler, adayın sahip olması gereken özellikleri ifade etmektedir. İncelenen iş ilanlarının bazılarında genel nitelikler ve iş tanımı, iç içe geçmiş olup ayrı ayrı belirtilmemiştir. Araştırmada, genel nitelikler" ve "iş tanımı" nın ayrı ayrı belirtilip belirtilmediği incelendiğinde önemli bir husus göze çarpmaktadır. Servis, mutfak ve kat hizmetleri departmanlarına ait pozisyonların oda kahvaltı hizmet veren 5 yıldızlı otellerin ilanlarının \%70'den fazlasında "genel nitelikler" ve "iş tanımı" ayrı ayrı belirtilmiştir.

Günümüzde müşteriler için istedikleri kriterlere uygun hizmet kalitesi yüksek bir otel bulmak için önceki müşterilerin oluşturduğu puanlama sistemleri büyük önem taşımaktadır. Konaklama işletmeleri açısından otel puanı sadece müşseri çekmek için değil, nitelikli eleman bulmak içinde önemli bir kriterdir. Tüketicilerin yaygın olarak kullandığ 1 ve konaklama işletmelerine puan verdikleri yaygın kullanılan sitelerden biri olan Trivago sitesinde yer alan işletme puanları incelendiğinde; 9,1 ve üzeri puan alan otellerin \%55'inin ilanında iş tanımı ayrı olarak yer almaktadır. Yine 9,1 ve üzeri puan otellerin \%75'inin iş ilanında görsel (logo, fotoğraf, video vb.) bulunmaktadır. Puanı yüksek olan 
otellerin nitelikli eleman bulmak için iş ilanlarına daha fazla önem verdikleri söylenebilir. İlanda yer alan otellerin kelime sayısı incelendiğinde, iş ilanında en fazla kelimeyi kullanan oteller 8,6 - 9,0 puan arası otellerdir. Bu puan aralığındaki işletmeler gerek puanlarını sabit tutmak gerekse yükseltmek amacıyla hizmet kalitesini arttırma çabasıyla daha kalifiye eleman bulmak için daha ayrıntılı veya özenli ilan verdiği söylenebilir. Otellerin çalışma sürelerine göre iş ilanları incelendiğinde, sezonluk eleman arayan otellerin iş ilanlarında daha çok kelime ve daha fazla görsel kullandıkları görülmektedir. Bunun sebebi, kısa süre hizmet verecek olmalarından dolayı personel yetiştirmek yerine, yetişmiş uygun personeli bulmak olabilir.

İş ilanında adaya sağlanacak imkanların belirtilmesi oldukça önemli bir konudur. Birçok çalışmada da bu tür bilgilerin iş ilanında bulunmasının adayları etkilediği sonucuna ulaşılmıştır. Bu sebeple nitelikli eleman arayan işletmelerin adayları çekmesi için ilanın cezbedici olması gerekmektedir. Bu çalışmada incelenen ilanların büyük bir kısmında adaya sağlanacak sosyal imkanlar/yan haklar bilgisine yer verilmediği görülmektedir. Bu bilgi sadece 5 yıldızlı otellerin küçük bir kısmında vardır. Blackman (2006) çalışmasında, iş ilanlarında adayları etkileyen en önemli faktörden birinin 'sosyal imkanlar ve kariyer olanakları ile ilgili bilgiler' olduğu sonucuna ulaşmıştır. Alnıaçık (2016) çalışmasında ise iş ilanında, ilana başvuracak adaylara sunulacak olan olanaklara ilişkin bilgiler vermenin, ilana yönelik tutumu da olumlu yönde etkilediği sonucuna ulaşmıştır. Konaklama işletmelerinin nitelikli elemanı işletmeye çekebilmek ve geniş bir aday havuzu oluşturmak için bu bilgiye iş ilanlarında mutlaka yer vermeleri gerektiği söylenebilir. İş başvurusu yapan adaylar, bir iş pozisyonunun kendileri için uygun olup olmadığını değerlendirmek amacıyla ayrıntılı bilgiye ihtiyaç duymaktadırlar. Adaylar, iş arama sürecinde ilan edilen iş pozisyonları için görev tanımı, ücret ve yapılacak diğer ödemeler, eğitim ve kariyer olanaklanı gibi bilgileri değerlendirirler (Cable vd. 2000). Yeteri kadar bilgi içermeyen bir iş ilanı adayların o pozisyon için uygun olmadıklarını düşünmelerine sebep olabilir. Nitelikli adayları işletmeye çekebilmek için ilanda ayrıntılı bilgiye yer vermek konaklama işletmeleri için çok önemli bir husustur.

Türkiye coğrafi olarak sezonluk turizm imkanlarına daha fazla sahip olduğundan, konaklama işletmelerinin faaliyet gösterdiği kısa dönem içerisinde işini en iyi yapabilecek personele sahip olması neredeyse bir zorunluluktur. Bu sebeple ihtiyaç duyulan pozisyona iş ilanı verilirken iş tanımının yanı sıra yapılacak işin kalitesi hakkında ipuçları verecek bilgiler de sunulmalıdır. Bu bilgiler, işe talip olan kişiyi iş başvurusundan vazgeçirecek kadar değil, bu işletmede işe başladığında ne kadar özenli çalışması gerektiğini anlatacak kadar olmalıdır. İlanlar, gerek görsel kullanımı gerekse diğer içerikler ile kurumsal kimliğin bir parçası olacağını adaya göstermelidir. İlanda yer alacak işgörene sunulan imkanlara ait bilgiler, işletmenin size değer veriyoruz mesajı olacağından mutlaka belirtilmelidir.

$\mathrm{Bu}$ çalışmada ortaya çıkan bulgular, iş ilanlarına başvuracak adaylar üzerinde yapılabilecek çeşitli çalışmalarda karşılaştırma olarak kullanılabilir. Ortaya çıkarılan bulgular doğru iş ile doğru adayın buluşmasında iş ilanı içeriklerine ait kriterlerin önemi hakkında bilgiler sağlayabilir. Sonraki çalışmalar için farklı zamanlarda verilen ilanların farklı kriterlere sahip olacağı düşünüldüğünden turizm sezon öncesi, sezon ortası ve sezon sonrası ilanların incelenmesi önerilebilir. Ayrıca çalışmanın yapıldığı zaman diliminde küresel salgın sürecinin etkileri turizm işletmelerine ait iş ilanlarının sayısı ve kriterlerini etkilemiş olabileceği düşüncesiyle, küresel salgın sürecinin etkilerinin geçtiği bir zaman diliminde yapılması da önerilebilir. Yine aynı süreçten dolayı bu çalışmadaki iş ilanları bölgesel veya şehir bazında yeteri sayıda dağılmaktadır. Yapılacak başka bir çalışmada iş ilanı kriterlerinin bölgesel veya şehir bazında farklılık gösterip göstermediği de incelenebilir. Sonraki çalışmalar konaklama işletmeleri dışındaki diğer turizm işletmeleri üzerinde yapılabilir. Böylece turizm işletmelerinin personel seçme kriterleri birbirleri ile kıyaslanabilir. Son olarak bu çalışma, Türkiye'deki konaklama işletmelerinin verdiği iş ilanları ile sınırlıdır. Araştırmacılara farklı ülkelerdeki işletmelerin iş ilanlarını incelemeleri ve kıyaslama yapmaları önerilebilir. 
Kaynakça

Acarlar, G. ve R. Bilgiç. (2013). Factors influencing applicant willingness to apply for the advertised job opening: the mediational role of credibility, satisfaction and attraction, The International Journal of Human Resource Management, 24(1): 50-77.

Allen, D. G., Van Scotter, J. R., ve Otondo, R. F. (2004). Recruitment communication media: Impact on prehİre outcomes, Personnel Psychology, 57(1), 143.

Alniacik, E. (2016). İş ilanlarının çekiciliği: mesaj belirginliğinin etkisi, Ege Academic Review, 16(1).

Audretsch, D.B. ve A.R. Thurik. (2000). Capitalism and democracy in the 21 century: from the managed to the entrepreneurial economy, Journal of Evolutionary Economics 10 (1), 17-34.

Audretsch, D.B. ve A.R. Thurik. (2001). What is new about the new economy: sources of growth in the managed and entrepreneurial economies, Industrial and Corporate Change 10(1), 267-315.

Barber, A. E., ve Roehling, M. V. (1993). Job postings and the decision to interview: A verbal protocol analysis, Journal of Applied Psychology, 78(5), 845.

Basım, H. N., Şeşen, H. ve Şeşen, E. (2008). Personel temin sürecinde gazete ilanları üzerine karşılaştırmalı bir çalışma, Gazi Üniversitesi Ticaret ve Turizm Eğitim Fakültesi Dergisi, (1), 3544.

Baş, T., Aydinlik, A. Ü. ve Erenel, F. (2011). Üniversite öğrencilerinin işveren seçim kriterlerinin belirlenmesine yönelik keşfedici bir araştırma, Ege Akademik Bakış, Temmuz, 11(3), 439-452.

Batman, O. (1999). Otel işletmelerinin yönetimi. Adapazarı: Değişim Yayınları.

Beardwell, J. ve Claydon, T. (Eds.). (2007). Human resource management: A Contemporary Approach. Pearson Education.

Belt, A. ve Paolillo, J. (1982), The influence of corporate image and specificity of candidate qualifications on response to recruitment advertisement, Journal of Management, 8: 105-112.

Blackman, A. (2006). Graduating students' responses to recruitment advertisements, Journal of Business Communication, 43(4): 367-388.

Boxall, P. (2003). HR strategy and competitive advantage in the service sector, Human Resource Management Journal, 13(3), 5-20.

Brantlinger, E., Jimenez, R., Klingner, J., Pugach, M., ve Richardson, V. (2005). Qualitative studies in special education, Exceptional Children, 71(2), 195-207.

Breaugh, J. A., ve Billings, R. S. (1988). The realistic job preview: Five key elements and their importance for research and practice, Journal of Business And Psychology, 2(4), 291-305.

Cable, D.M., Aiman-Smith, L., Mulvey, P.W. ve Edwards, J.R. (2000). The sources and accuracy of job applicants' beliefs about organizational culture, Academy of Management Journal, 43: 10761085.

Cable, D. M., ve Graham, M. E. (2000). The determinants of job seekers' reputation perceptions, Journal of Organizational Behavior, 21(8), 929-947.

Chen, L. H., Liaw, S. Y. ve Lee, T. Z. (2003). Using an HRM pattern approach to examine the productivity of manufacturing firms-an empirical study, International Journal of Manpower.

Cho, J. (2005). Human resource management, corporate governance structure and corporate performance in Korea: a comparative analysis of Japan, US and Korea, Japan and the World Economy, 17(4), 417-430.

Cho, S., Woods, R. H., Jang, S. ve Erdem, M. (2006). Measuring the impact of human resources management practies on hospitality firm's performances, International Journal of Hospitality Management, 25(2), 262-277.

Elo, S. ve Kyngas, S. H. (2008). The Qualitative Content Analysis Process. Journal of Advanced Nursing, 62(1): 107-115.

Erdem, B. ve T., Gezen. (2014). Turizm işletmelerine yönelik iş ilanlarının içerik analizi yöntemiyle incelenmesi, Uluslararası Yönetim İktisat ve İşletme Dergisi, 10(21):19-42.

Ertaş, Ç. (2018). Turizm sektöründeki nitelikli çalışan eksikliğinde turizm işletmelerinin payı: iş ilanları üzerinden bir inceleme, Adlyaman Üniversitesi Sosyal Bilimler Enstitüsü Dergisi, (30), 11431172 .

Feldman, D.C., Bearden, W.O. ve Hardesty, D.M. (2006). Varying the content of the job advertisements: the effects of message specificity, Journal of Advertising, 35: 123-141.

Fernandez, K.V. ve D.L. Rosen. (2000). The effectiveness of information and color in yellow pages advertising, Journal of Advertising, 29(Summer), 61-73. 
Fisher, C.D., Ilgen, D.R. ve Hoyer, W.D. (1979). Source credibility, information favorability and job offer acceptance, Academy of Management Journal, 22: 94-103.

Gatewood, R.D., Gowan, M.A. ve Lautenschlager, G.J. (1993). Corporate image, recruitment image, and initial job choice decisions, The Academy of Management Journal, 36: 414-427.

Goltz, S.M. ve C.M. Giannantonio. (1995). Recruiter friendliness and attraction to the job: the mediating role of inferences about the organization, Journal of Vocational Behavior, 46(1): 109-118.

Heffernan, M. M. ve Flood, P. C. (2000). An exploration of the relationships between the adoption of managerial competencies, organisational characteristics, human resource sophistication and performance in Irish organisations, Journal of European Industrial Training, 24(2-3), 128-136.

Hogan, J. J. (1992). Turnover and what to do about it. Cornell Hotel and Restaurant Administration Quarterly, 33(1), 40-45.

Hoque, K. (2013). Human resource management in the hotel industry: Strategy, innovation and performance. Routledge.

Huselid, M. A. (1995). The impact of human resource management practices on turnover, productivity, and corporate financial performance, Academy of Management Journal, 38(3), 635-672.

İşte Çanakkale (2019). Turizmde istihdamda mezun oranı arttırllmalı, 01 Haziran 2020 tarihinde http://www.istecanakkalegazetesi.com/haber/9558-turizmde-istihdamda-mezun-orani-artirilmali adresinden erişildi.

Kaplan, A. B., Aamodt, M. G. ve Wilk, D. (1991). The relationship between advertisement variables and applicant responses to newspaper recruitment advertisements, Journal of Business and Psychology, 5(3), 383-395.

Kariyer.net. (2020). 01 Haziran 2020 tarihinde https://www.kariyer.net/kurumsal/hakkimizda adresinden erişildi.

Koç, E. (2003). The role and potential of travel agency staff as a marketing communications tool, Tourism Analysis an Interdisciplinary Journal, 8 (1), 105-111.

Koç, E. (2012). Tüketici davranışı ve pazarlama stratejileri: global ve yerel yaklaşım: pazarlama ve tüketici davranışı kavramlarının Ingilizceleriyle. Seçkin Yayıncıllk.

Koç, E. (2016). Hizmet Pazarlaması ve yönetimi: global ve yerel yaklaşım. İstanbul: Seçkin Yayıncılık.

Lee, C. H., Hwang, F. M. ve Yeh, Y. C. (2013). The impact of publicity and subsequent intervention in recruitment advertising on job searching freshmen's attraction to an organization and job pursuit intention, Journal of Applied Social Psychology, 43(1), 1-13.

Mason, N., ve J.A. Belt (1986). Effectiveness of specificity in recruitment advertising, Journal of Management, 12(September): 425-432.

Milliyet (2018). Turizmde en büyük eksiğimiz kalifiye eleman, 01 Haziran 2020 tarihinde https://www.milliyet.com.tr/tatil/turizmde-en-buyuk-eksigimiz-kalifiye-eleman-2608349 adresinden erişildi.

Oğuzbalaban, G. (2019). Konaklama işletmelerine yönelik iş ilanlarının içerik analizi: turizm gazetesi örneği, Karadeniz Sosyal Bilimler Dergisi, 11(21), 461-473.

Premack, S. L., ve Wanous, J. P. (1985). A meta-analysis of realistic job preview experiments, Journal of Applied Psychology, 70(4), 706.

Reeve, C.L. ve Schultz, L. (2004), Job-seeker reactions to selection process information in job ads, International Journal of Selection and Assessment, 12: 343-355.

Roberson, Q. M., Collins, C. J. ve Oreg, S. (2005). The effects of recruitment message specificity on applicant attraction to organizations, Journal of Business and Psychology, 19(3), 319-339.

Roberts, K. (1995). The proof of HR is in the profits. People Management, 1(3), 42-43.

Rynes, S. L. ve Miller, H. E. (1983). Recruiter and job influences on candidates for employment, Journal of Applied Psychology, 68(1), 147.

Saçkes, E. ve M., Doğdubay. (2019). Konaklama işletmelerinin pazarlamasında mobil teknolojinin kullanım1, Global Journal of Economics and Business Studies, 8(16), 183-195.

Schermerhorn, J.R. (2001). Management Update 2001, 6th ed, New York, John Wiley and Sons, Inc.

Schneider, B., Smith, D. B., ve Goldstein, H. W. (2000). Attraction-selection-attrition: Toward a person-environment psychology of organizations, Lawrence Erlbaum Associates Publishers.

Stalcup, L. D. ve Pearson, T. A. (2001). A model of the causes of management turnover in hotels, Journal of Hospitality and Tourism Research, 25(1), 17-30. 
Şit, M. (2016). Türkiye'de turizm sektörünün istihdama katkısı, Akademik Yaklaşımlar Dergisi, 7(1), 101-117.

Turban D.B. ve D.W. Greening. (1996). Corporate Social Performance and Organizational Attractiveness to Prospective Employees, Academy of Management Journal, 40 (June): 658-672.

Turizm Günlüğü (2018). Turizmde personel sikıntısı ne durumda? 01 Haziran 2020 tarihinde https://www.turizmgunlugu.com/2018/07/24/turizmde-personel-sikintisi-ne-durumda/ adresinden erişildi.

Turizm Günlüğü (2019). Turizm Sektörünün Eğitimli Sahipleri Nerede? 01 Haziran 2020 https://www.turizmgunlugu.com/2019/09/30/turizm-egitimi-fatih-kartal/ adresinden erişildi.

UNTWO (2019). Growth in international tourist arrivals continues to outpace the economy, 01 Haziran 2020 tarihinde https://www.unwto.org/world-tourism-barometer-n18-january-2020 adresinden erișildi.

Wasmuth, W. J. ve Davis, S. W. (1983). Managing employee turnover, Cornell Hotel and Restaurant Administration Quarterly, 23(4), 15-22.

Wood, S., Holman, D. ve Stride, C. (2006). Human resource management and performance in UK call centres, British Journal of Industrial Relations, 44(1), 99-124.

Wright, P. M. ve Boswell, W. R. (2002). Desegregating HRM: A review and synthesis of micro and macro human resource management research, Journal of Management, 28(3), 247-276.

Yenipınar, U. (2005). Otel işletmelerinde ücretlendirme: İzmir ili 4-5 yıldızlı otel işletmelerinde bir analiz, Dokuz Eylül Üniversitesi Sosyal Bilimler Enstitüsü Dergisi, Cilt:7, Sayı:3.

Yüce, P. ve Highhouse, S. (1998). Effects of attribute set size and pay ambiguity on reactions to "help wanted" advertisements, Journal of Organizational Behavior, 19: 337-352.

\section{Etik kurul onayı}

Çalışmanın anket, mülakat, odak grup çalışması, gözlem, deney, görüşme teknikleri gibi teknikleri içermemesi sebebiyle etik kurul izni gerektirmeyen çalışmalar arasında yer aldığını beyan ederiz.

\section{Araştırmacıların katkı oranı beyanı}

Yazarlar çalışmaya eşit oranda katkı sağlamıştır.

Çıkar çatışması beyanı

Bu çalışmada herhangi bir potansiyel çıkar çatışması bulunmamaktadır. 